\title{
KENNETH MACGOWAN, 1888-1963
}

\author{
Joseph A. Hester, JR.
}

$\mathrm{M}$ ORE THAN HALF a century of outstanding professional activity came to a close on April 27, 1963, for Kenneth Macgowan, famed author, drama critic, director and producer of stage and screen, university professor, and internationally recognized amateur in archaeology. His eminently successful theatrical, literary, and academic careers have been summarized elsewhere; they need only be mentioned here.

In archaeology Macgowan's interests were broad in scope and more than casual. His name first appeared in the membership lists of this Society a quarter of a century ago, followed in a few years by membership in the American Anthropological Association and related groups. Frequently an interested spectator at our national and local meetings, he served in 1946 as president of the southern California branch society of the Archaeological Institute of America. He participated actively in seminars and doctoral examinations in archaeology and characteristically sought out and consulted with experts in this and related fields to keep abreast of new developments. His knowledge of archaeology, notably in the specialized field of early man, often was ahead of publications on that topic. He not only assembled but also assimilated an impressive library on archaeology. Most of this was presented to the Department of Anthropology and Sociology at the University of California at Los Angeles, beginning in 1954 with a gift of more than 900 items and followed from year to year with gifts of additional volumes.

Sometimes a compilation of one's publications provides a useful index to professional achievement. Macgowan's many publications, however, are for the most part in other disciplines; an enumeration here would serve only to obscure his considerable interests in and influence upon archaeology and anthropology. While he attempted no basic research in either field, he published in both. As early as 1923 his lifelong attention to art and drama was expressed upon an ethnological topic when, with Herman Rosse, the book Masks and Demons was published. Essentially an album of primitive masks, this called the layman's attention to the dramatic religious art of primitive peoples. One assumes that these masks were part of Macgowan's own extensive and often-displayed collection which became one of the most notable ever privately assembled.

Macgowan was given the impressive title of Director of Production for the Motion Picture Division of the Office of the Coordinator of Inter-American Affairs, and in 1941-42 he produced a number of documentary and educational films on Latin America. These included films on archaeological and other subjects which do not always list his name among the credits. Later, an interest in Mexican archaeology prompted a comment in American Antiquity (Vol. 11:118) on the orientation of major ruin sites and structures. More recently in Hollywood he produced for the United Fruit Company a feature-length film, "The Maya through the Ages." This concerned the Lacandon and Chamula and documented the discovery of the Bonampak murals. He modestly referred to this as an amateur production, although it featured superb color photography by Giles Healey and sensible narration by three of Hollywood's most illustrious artists. Typical of his later "amateur" films was a short dramatic presentation, "Color of Man," which dealt somewhat abstractly with the environmental aspects of race and human genetics, and was produced in collaboration with anthropologists at the University of California at Los Angeles.

Macgowan's most substantial publication in archaeology was Early Man in the New World, which was conceived by George C. Vaillant as the introduction to and background for an extensive volume on American prehistory. Vaillant was to provide a summary of Middle American archaeology and William Duncan Strong an equivalent statement for South America. At Vaillant's death the major project was abandoned, but Macgowan's investment in time, effort, and interest already had carried him beyond the "point of no return." Subsequently, and despite the concurrent burdensome task of building the Theater Arts Department and facilities (University of California at Los Angeles), with its myriad attendant activities, this section was expanded, published separately as a book in 1950, and then revised as a paperback in 1962. It was not a professional opinion of his 


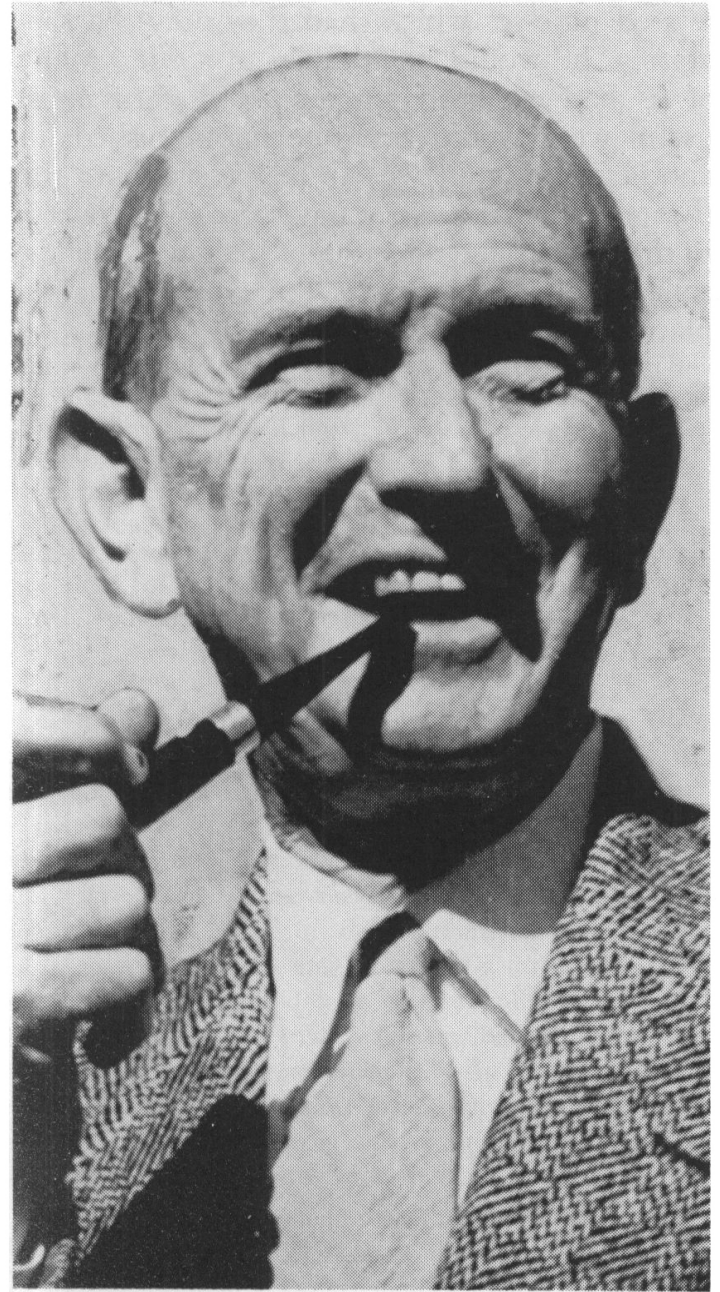

Kenneth Macgowan

own but rather a summary, more or less with historical perspective, of the development of knowledge of Old World culture and fossil men, and their earliest American heirs. It provided an expression of Macgowan's exceptional literary talents and his facility for graphic and verbal illustration. Commenting on this work, Duncan Strong wondered: "Why a famed producer, writer and teacher on theatrical and allied subjects should most seriously turn his hand to the still very dim, controversial and highly technical story of human and cultural origins in the New World is hard to guess. Perhaps it is the dramatic background of vast voiceless continents, giant beasts, and furtive but bold human pioneers . . . which brings this most modern man into the 'early man' arena." Gor- don F. Ekholm observed recently that, while Macgowan professed to be an amateur in archaeological matters, his competence in the extraordinarily involved subject of early man was "certainly of professional stature."

Most typically, Macgowan's contributions in anthropology were behind the scenes, and were in a larger sense catalytic rather than participant. At the time of his death he was a member of the Board of Trustees of the Southwest Museum in Los Angeles. He also served as a member of the awards committee of the John Hay Whitney Foundation. Less directly, under his chairmanship the Theater Arts Department of the University of California at Los Angeles encouraged student cinematography of documentary topics properly within the scope of anthropology, at times of remote primitive peoples not yet studied by anthropologists. For the archaeologist he often provided entrée for the study of private collections of primitive art and archaeological specimens.

Macgowan was a 1911 graduate of Harvard University and maintained an identity with that institution, exemplifying for many those cultivated superlatives cherished by Harvard as its public image. His prodigious span of activity was emphasized in March of 1962 when, with obvious relish, he wrote: "I am going to teach at the Harvard Summer School this July and August, where I took a course in solid geometry fifty-five years ago." Although illness dictated otherwise, it did not preclude completion during the ensuing year of a new book on the theater. His statement accentuates more than five decades of accomplishment, culminating at the University of California at Los Angeles where, in 1959, following his retirement from the faculty, an appreciative University of California formally recognized his academic stature with a Doctorate of Laws. As a tribute to his foresight, judgment, and considerable efforts in this field, the splendid new theater arts building was named Macgowan Hall in his honor.

He had a way with words and, as befitted his enormous talents, he was not only an absorbing speaker but also an excellent listener. Fifteen years ago I first knew Macgowan as a distinguished theatrical personage and teacher, with an interest in archaeology. I learned to respect his powers of observation, thought, and logic, and not to underestimate his capacity for scientific knowledge. My admiration for him as a scholar and as a person increased steadily as 
each passing year disclosed new and often unexpected facets of personality, knowledge, or achievement. I came to know him as a delightful, first-rate human being, as an exceptionally honest, courageous, and practical man of unpretentious generosity. His boundless enthusiasm for life and work was tempered by a delightful sense of humor, both sparked with an endless productive energy which was the envy of colleagues half his years. One can scarcely escape the conclusion that his death, midway in his 75th year, was premature, precipitated by a concatenation of serious but seemingly un- related illnesses which, had they occurred separately, he would have taken in stride. Many of us had expected and hoped that his most useful work would continue undiminished for another decade or two. In his passing both the theater and archaeology have lost a benefactor; in the esteem and affection of his many friends, colleagues, and associates there can be no replacement for this great and kindly man.

San Jose State College

San Jose, California

August, 1963 